\title{
Technology Guidance and Counselling: \\ Implementation Theory in Practice, Development and Experience
}

\author{
Eko Susanto, M.Pd., Kons. \\ Email: ekobkummetro@gmail.com \\ Mobile: +6281369149853 \\ Muhammadiyah University Metro \\ Yuni Novitasari, M.Pd. \\ Email: unie69@yahoo.co.id \\ Mobile: +62821 21984590 \\ Muhammadiyah University Metro
}

\begin{abstract}
This article is a testimony of the results of practical experience and literacy studies on group counseling and group counseling. Since 1905 as the beginning of develop the group acknowledged that the approach is often effective to create an atmosphere that therapy can help people solve problems. Not only that certain groups are also often used for training and means of sharing information. The fact remains found in the field of school counselors who have difficulty in organizing group activities. This article attempts to answer the question (1) how carry out the theory into practice group, (2) develop a model of group activities, (3) the author's experience in the group activities, (4) technology in group activities. Hope the author after reading this article and follow the workshop, will appear enlightenment that can stimulate the school counselor carry out the group's activities in school.
\end{abstract}

Keywords: group guidance, group counseling, theory, technology, implementation

\section{Presented :}

December 16, 2014

International Seminar and Workshop on Guidance and Counseling

Indonesian Education University

\section{Seminar and Workshop Theme :}

The Current Issues and Trends of Guidance and Counseling and Their Implication on The Standardization of Counselor Education

\section{Publish :}

Proceeding of International Seminar and Workshop on Guidance and Counseling ISBN : 978-602-72729-0-3 


\section{INTRODUCTION}

Guidance and counseling means a systematic, objective, logical, and sustainable and programmed conducted by school counselors to facilitate the development of the counselee to achieve selfreliance in life (Permendikbud No. 111 2014). Guidance Group is one of the strategies of guidance and counseling services in schools. Group counseling is more educative, preventive and informative are presented in the form of small groups to discuss general topics and not secret. Group counseling is also designed as a means to develop new skills or behaviors that are more effective and productive (MONE, 2008). Since 1905 as the beginning of the development of the group acknowledged that the approach is often effective to create an atmosphere that therapy can help individuals solve problems (Gladding, 2012). Not only that certain groups are also often used for training and a means of sharing information. The effectiveness of group counseling has been widely demonstrated in a variety of research activities, for example research Rosidah (2013), which proves that the guidance of the group with a game technique effective for improving individual adjustment. In another study Suryani (2012) shows the effective group counseling to improve students' ability to manage the stress of school.

Slightly different from group counseling that is more terapiutik, curative, responsive and confidential. Group counseling can also be given as an aid to endorse counselees face crisis conditions. Group counseling more help to reach the counselee in the process, this activity is more effective than individual counseling activities. Ministry of Education (2008) describes a group counseling is intended to help students who are having difficulty, have problems in achieving development tasks. Counselee in the process helped to know why the problem, find solutions and make decisions that are right for him. Group counseling in principle is individual counseling activities were held in the atmosphere of the group. The support group can facilitate individuals to resolve the problem. Group cohesiveness is built is believed to provide a profound psychological support for individuals who have problems.

In the reality in the field is still found a school counselor who experienced problems in the organization of group activities. Constraints experienced can generally be divided into two: (1) internal constraints; counselor associated with the knowledge, skills, confidence, self-confidence and ability counselor, (2) external constraints; good systemic school admissions related to guidance and counseling, scheduling, time; or structural for counselors who have certain positions. Although not all school counselors constrained to the above, but in general, many a dilemma faced by the school counselor. This article does not discuss this issue more deeply, but will focus on answering the following questions; (1) how the implementation of group theory into practice, (2) develop a model of group activities, (3) the author's experience in the service group, (4) technology in group 
activities.

Answering the first question, how the implementation of group theory into practice. Community counseling profession still I hear the words of pessimism associated with the implementation of theory into practice. The phrase "this is not such practices exist in theory", indicating as if the theory is difficult to implement. If so, the school counselor who said it had been working with do not use the theory in practice. Such practice is hazardous, if in practice is not based on a theory. In everyday life it is often the perception that mengdikotomi between theory and practice. It is possible a different theory to the reality, and perhaps also contradictory. Therefore a lot of research done -riset-just to test a theory. In science, theory means a model or frame of mind that explains natural phenomena or certain social phenomena. Theory was formulated, developed, and evaluated according to scientific method. Theory is also a hypothesis that has been proven true. Humans construct theories to explain, predict, and control of certain phenomena, for example, inanimate objects, natural events, human behavior even animal behavior (Wikipedia, 2014).

In other references mentioned theory is a set of concepts and principles that explain and predict phenomena. There are two kinds of theories, namely the theory of intuitive and scientific theory. Intuitive theory is a theory built on the basis of practical experience. While the scientific theory (formal theory) is a theory built on the basis of research results. Teachers in schools more often use the theory of the first type (Agustina, 2012). From some of these definitions can be understood that the theory can be used as a reference in practice, therefore, the practice undertaken by school counselors should not be separated from the underlying theory of guidance and counseling services. According to Suppes (in Bell, 1986) there are four general theory of functions, namely: (1) is useful as a framework to conduct research; (2) provide a framework for organizing a grain of certain information; (3) identification of complex events; (4) reorganization of previous experiences. Of some of the functions described in the practice of a theory function is to provide a framework that guides the practice done. Theory is also built on the basis of past experiences. In the context of BK, theory can accurately describe, understand, explain the relationships between variables in a phenomena, and then predict and control (intervene) other phenomena or at any other time with regard to the behavior of the counselor and counselee in any activity of guidance and counseling. One theory, for example, able to precisely explain what is causing the problem counselee, deliver predictions about the response and behavior of the counselee, and offers a relevant technique as a control or a particular solution for problems of counselees is, in fact solutions for the growth and development of the counselee in the future ( Adi Atmoko, 2010). The bottom line with the theory of school counselors can help with the process steps correctly and already accompanied by signs that may be and not to be done. Appeal to the school counselor to continue to increase his 
knowledge by reading a variety of sources that can be accounted for. Continue to increase knowledge, new understanding, a new paradigm, a new theory and new concepts related to guidance and counseling. Development counselor through supporting information update to embody professionalism guidance and counseling services provided.

Answering the second question, to develop a model of group activities. Of much literature, foreign literacy on guidance and counseling are often studied by counselors and prospective counselors in Indonesia. In practice there are many who refer to the western psychological theories such as psychoanalysis, behaviorime and humanism. Psychoanalysis looked at the nature of human behavior and personality historically were largely determined by the results of the development in the past. Human behavior is formed on sexual drive and aggressiveness with essentially the motive to seek pleasure and unconsciousness. The flow of human behaviorism is not considered to be good and bad behavior are formed from learning from the environment. Different with the flow of humanism holds that humans have personal values, awareness, potential, responsibility and the freedom to grow and develop positively. This view emphasizes the self acknowlege function and optimistic.

In addressing various western theories that developed into Indonesia, there should be a filtration of the western theory and can be applied to fit into the culture of Indonesia. This idea is very plausible, because a theory developed by using the working principle Deducto-hipoteticoverificatio which is inseparable from the condition of the field where data is collected for the purpose of building the theory. Although a theory claims to cover all things universally (ETICS), but in the process of preparation and implementation is not possible apart from the aspects of context (Emics). Therefore, the theory views the west (western oriented) are not always congruent to describe and understand what is happening dikonteks eastern society. Thus, the theory developed in the context of the west is definitely different from the context of the east, especially Indonesia (Miller, 1993; Salim, 2006; Atmoko, 2010).

In fact happening in the field use western theory in practice mostly done by a counselor at school. Even in the activities using the module PLPG instructor practicing western theories and applied strictly. Practice activity that was identified as one of the most correct source on which to base practice counselor at school. Often appear a "last can of PLPG so the instructor said," is ridiculous for me to hear such words. For prospective counselors on campus was thus learn many western theories that form the basis of guidance and counseling services in schools. Unfortunately both counselor or prospective counselors few realize the incongruity which occurs when the theory is practiced in schools. Atmoko (2010) describes Counseling rooted in western culture will use the 
concept in practice and the results were very likely not applicable for socio-cultural context of Indonesia. Concepts and how they are irrelevant in the face of issues of counselor and counselee Indonesia. For that, we need to start concentrating on the need to contextualize counseling, which empowers more culturally relevant and rooted in socio-cultural Indonesia.

Indigenization counseling by searching for cultural roots counseling west and adjust the settings of Indonesian culture, will keep us from the trap position of the two poles, the pole position of the radical extreme cultural relativism that hinder comparisons between cultures, while at the other side is that maintaining intellectual dominance western, mainstream counseling, with skepticism and prejudice against indigenous Indonesian counseling. With the indigenization counseling, we become Indonesian scientists who have views and positive thinking to the values, ideas and practices of local Indonesian useful for the development of counseling, have a critical mind that is worth the practice of counseling western and local, and encourages us to preserve local cultural identity in line with movement to become more integrated into the wider framework, and we do not blindly to reject the idea of foreign and west because it is considered bad (Atmoko, 2010). In constructing knowledge counselor would need to be preceded by an understanding of complex theory. Best practice can be done if the counselor has a lot of knowledge that can be used as a basis for understanding the counselee and the environment. Activities of group counseling and group counseling is closely related to the dynamics of the group that came from the meeting between individuals who have values, culture and environment of diverse origin. In such conditions the counselor should be able to inculturate the culture and values of the group in the counselor to bring genuine empathy. The counselor should also be able to unite individuals in group activities and build cohesiveness among them. It is not a matter that can not be done by counselors, instead of practical experience and findings in the field can be used as the basis to build an intuitive theory. The shape of the reflection theory of intuitive reports can then be used as information to build a more formal theory empirically tested.

Building a model of any such group activities can be initiated by entering a local cultural values into practice. For example, before conducting group counseling or group counseling begins with prayer. The seating position is not too close between the members of the male and female, embodying the values of mutual aid, solidarity, tolerance, tolerance, respect parents and the values of Western culture such as discipline, work planning, are values that need to be adopted (Asih Waiting, 2003).

In principle how the counselor in practice must be based on a proper view of the counselee assisted. So can improve the effectiveness of services provided, not stiff and formal impressed. For example, 
to build a family atmosphere as a form of technical adjustments to the home room in group counseling activities. Using the appropriate greeting in a region may be able to use the greeting "Ananda" but other areas may be less fit and seemed stiff and formal. In the thick regional conditions it is possible to use the greeting areas deemed more polite and showed a close relationship. The use of a single language Indonesian example will fit on a heterogeneous group. But for homogeneous groups use dual language will be more easily accepted and more memorable. That way school counselors should not be afraid to try out a model that is constructed itself into practice, which is important to have a foundation thought relevant. If fixed on one model only, the counselor will tend to blame the other different models. Practice by entering the values of the local culture tend to have a high level of acceptance from the group assisted.

The author's experience in group activities to answer the third question. In practice I have ever done it a valuable record as testimony. Although the record that I make tend to be pragmatic qualitative and subjective, but could be useful information for improving practices in the school counselor. I focus on the aspects of record sessions, number of sessions, group characteristics, the techniques in group activities.

\section{Related to the time each group counseling sessions and group counseling}

School counselor asked how long it ideal for use in group counseling sessions or group counseling? Before answering this question, should we need to understand the meaning of professional services. Are counseling and guidance with a long time can be called professional. Or services performed in a short time are not worthy to be called a professional service. My analogy with the services performed by a physician. When we come to the doctor for treatment we were greeted kindly by words suggestive to reconcile the patient. Be seated and asked with a friendly who is sick, what is perceived complaints, hospital section where, and chronology of the other as part of the diagnosis. Then do a check of blood pressure after completion welcome to lie in bed for further examination with a stethoscope. Once completed we welcome waiting for a prescription prepared by a doctor. Then we pay and go home, how much time is used to perform all of these processes? Think of it less than 7 minutes, whether the services performed by the doctor is a professional service? I concluded that the professional services are not always directly proportional to the time of service delivery. In principle the service is carried out either with a short or long time if done with the principles of professionalism, it can be called a professional service. The existence of a profession is very dependent on the recognition and confidence of users of the profession (public trust), the trust that arises because people with professions that (1) have the competence and expertise are prepared through education and special training, (2) there is a set of rules to regulate professional behavior and protect public welfare, (3) the members of the profession will work and provide services to cling to the standards of the profession (Biggs \& Blocher, 1986). Thus the explanation 
Biggs \& Blocher confirms that professional services are services based on the three traits mentioned. In guidance and counseling services are recognized counselors provide professional services, although done with a relatively short time like a doctor that my previous analogy. During the service of assistance given is based competence and expertise of the special education, there is a code of conduct services, and there are professional standards that run the service it is worth mentioning as professional services.

Relation to the ideal time implementation services group counseling sessions or group counseling is determined by three things. (1) The level of development of the group members for the members of the group with elementary school age to bottom should be less than 30 minutes for each session. Why this is so, the experience level of attention in the field of primary school students can not be constant for a long time. Of course it is associated with the period of their development. In some foreign references even so Missouri Comprehensive Guidance and Counseling Program set a time of 30 minutes for each session for a group of elementary school services. For high school age and above most minute and a maximum of 30 minutes can be adjusted to the members and deal with the counselor.

\section{Related to the number of sessions for each group}

In general, western references recommend 6 (six) to 8 (eight) for a group counseling session. However, we in Indonesia opinion, I do not need to get hung up on such a benchmark. At Permendikbud No. 111 of 2014 on the implementation of guidance and counseling services in primary and secondary schools have been related to the equivalence of time detailing the service commendable. Although K13 in moratorium but permendikbud can still be used as a reference in practice. Obviously the process to become a candy already gone through the process of analysis and consideration of expert guidance and counseling in Indonesia by taking into account the condition of the school counselor in Indonesia. In practice I always do group counseling services and group counseling at most 3 (three) sessions for a group. and most are less than 3 (three) sessions for each group. The effectiveness of the service that has always been associated with the efficiency of the service performed. That is a bit of a session conducted to show the effectiveness of the services provided. However, my statement is still to be tested further. Compare this with your experience so far how. I personally always limit of guidance counseling groups or groups of at most 3 (three) sessions for each group. I believe consecutive time the problems experienced by the counselee will disappear by itself, it is necessary to stimuli to encourage individuals separated from the problem. Through group activities of individual problems which have not been resolved will naturally disappear little by little. Individuals will mengkontruks information obtained in the first session to solve the problems they experienced. Usually this will be seen when they inquired 
further about an issue.

\section{Related to the characteristics of the group}

In general characteristics of the group can be divided into two groups of homogeneous and heterogeneous group. Homogeneous groups are groups that have similar characteristics in common example of a member of his group sex, religion, problems experienced, preferences or interests and so forth. While the heterogeneous group is the group that has the complexity of its membership in the example of the opposite sex, religion, cultures, different ages, different problems, different grade levels and so forth. Judging from the nature of the group can also be divided into two groups namely closed and open group. Closed group is the group that the membership can not be added, usually a counseling group. Open group is the group that the membership is still able to accept new members, possibly as a model or a guest, such is usually the group guidance. Counselors must be good to put a counselee in the right group that can help counselees resolve the problem. Placement of the group would not be separated from the need assessment has been done by the counselor. Sometimes the counselor can put a counselee intuitively based on experience and sensitivity counselor of the condition occurs, this may be done.

\section{In connection with the techniques in group activities}

In fact the practice of counselors are required to be interesting person in front of members of the group. Interesting in many aspects is determined by the state of the counselor itself. There may be a counselor rather quiet or calm but are seen as attractive in front of the group members. Even can also counselors who like humor is one of the aspects that appeal to members of the group. Thus every counselors need to explore the interesting side that is within each of them. Such exercises can be done with a reflection on each side of life counselor. Finished doing group activities as part reflection dig up information about the things that have been done by the counselor. After the counselor understand the desire is generally expected by the counselee of the counselor, then that's likely to be a personal counselor interesting. Many techniques can be used counseling and group activities carried out will be more attractive. When the group activities deemed attractive by the group members when the counselors are seen as attractive by the group members. Counselors can practice using the techniques of the game, home room, exercise, sociodrama and other technical innovations developed by the counselor. In the practical experience of group members generally prefer a counselor humorous and displays interesting things that are not obtained from the subject teachers. Appearances are expressive and funny story I often use to draw the attention of members of the group. I also often use morphology with a story to be able to enter the territory of the counselee self-acceptance. 
Technology in group activities to answer the fourth question. Hear the word technology can always be assured that terbesit in mind is a powerful tool and computerization. Though not always the case, said the technology refers to a tool or method that can facilitate someone do the job or achieve a goal. Technology dichotomy divided into advanced technology and simple technology. Technology is also not necessarily in the form of a real object, it may be shaped something abstract and systemic that can only be felt once all go through the process. For example in the study of educational technology is closely related to efforts to simplify deliver instructional information to students. This can be done in design learning models are attractive, that forms abstract and systemic technology I mean.

Models of counseling and guidance techniques can also be called as a technology that abstracts and systemic nature. Electronic devices used in the classical activities such as LCD and Laptop is a technology that is material that can be in touch. Another of the so-called simple technologies are all things that are made conventionally to help facilitate the work of counselors. For example, the guidance board is a simple technology is a sophisticated technology that enabled Blog or Website together with the guidance of the board. Box problem is simple technology, sophisticated technology is SMS or social networking inbox owned by the school counselor.

\section{METHODS}

The approach used is a qualitative approach which emphasizes the significance of an event, the reality and the unique relationships within the practice of guidance and counseling groups. The method used in writing this article is descriptive. Interpretation is presented based on the study of literacy, experience and the results reflect the practice field.

\section{RESULTS AND DISCUSSION}

Results of this article gives a note to the school counselor to be able to provide a professional service. Especially in the activities of group counseling and group counseling can consider four issues related to the session time, number of sessions, group characteristics, the techniques in group activities. As I mentioned earlier counselor should dare to start to collect records his experiences. Then construct that experience into a new approach menadaptasi local culture. Counselors need to continue to learn to be personally interesting and fun. Technological developments have been realized or not an impact on the working environment counselor. The counselor should understand the function of the technology in order to improve the professionalism of counselors. Implementation of the use of technology in guidance and counseling services must pay attention to the function of the technology itself. The first technology functioned as a supplement in guidance and counseling services. It means that the technology is used only as an adjunct in the process of 
counseling, counselee given the freedom to use it or not. For example after the counseling process ends counselor offers to chat in the evening, chatting here serves as an adjunct of the counseling process during the day, the counselee may receive counselor may also not offer such. Both technologies functioned as a complement in guidance and counseling services. It means that the technology is used as a complement to the assistance provided by counselors and had been planned by counselors to use these technologies. For example the use of LCD and Laptop in the activities of the group to display images or videos. The third technology functioned as a substitute in guidance and counseling services. Where technology really replace the presence of a counselor before counselee. For example, the process of counseling through the Internet by using a gadget or laptop, technology here replace the presence of a counselor who can not face to face with the counselee because the counselor was out of town. Thus the use of technology does not necessarily have to be done, but it can be used as needed. The use of technology also need to consider the function of the technology itself, not to the negligence of using technology raises new problems for counselors.

\section{CONCLUSION}

Meaningfulness of aid for the counselee more mainstream than the techniques and technology used in providing assistance counselor. The counselor was a human being who has advantages and disadvantages. Counselors also may have a problem, the problem itself is a risk that must be borne by everyone. The problem may not be eliminated absolute zero, which can be done by the counselors is to minimize the emergence of the problems in her life.

\section{REFFERENCES}

Adi atmoko. (2010). Penerapan ICT dalam Pengembangan Keilmuan Bimbingan dan Konseling Indonesia. Seminar Nasional Revitalisasi Keilmuan Bimbingan dan Konseling DalamPendidikan. Bandung: Universitas Pendidikan Indonesia

Bell Gredler, E. Margaret.1991. Belajar dan Membelajarkan. Jakarta: CV. Rajawali

Biggs, Donald A. \& Blocher H. (1986). The Cognitive Approach To Ethical Counseling:Values in Counseling Ethic. New York: State University of New York at Albany.

Depdiknas.2008. Bimbingan dan Konseling di Sekolah. Bahan Belajar Mandiri Musyawarah Kerja Pengawas Sekolah, Jakarta: Direktorat Jenderal Peningkatan Mutu Pendidik dan Tenaga Kependidikan.

Menanti, Asih. (2003). Konseling Indigenous (Indigenous Counseling). Konvensi Nasional XIII Bimbingan dan Konseling. Bandung: Universitas Pendidikan Indonesia.

Rosidah, Ainur. (2013). Efektivitas Teknik Permainan Dalam Bimbingan Kelompok Untuk Meningkatkan Penyesuaian Diri Siswa : Studi Kuasi Eksperimen Terhadap Siswa Kelas Vii Smp Negeri 29 Bandung Tahun Ajaran 2012/2013 (Thesis, Universitas Pendidikan Indonesia) 
Suryani, Yani. (2012). Program Bimbingan Kelompok Untuk Meningkatkan Kemampuan Siswa Mengelola Stres Sekolah : Studi Kuasi Eksperimen Terhadap Siswa Kelas X Madrasah Aliyah 99 Persis Rancabango Tahun Pelajaran 2011/2012 (Thesis, Universitas Pendidikan Indonesia)

Ismaya Dwi Agustina. (2014). Pengertian Teori. (Online). http://ismayadwiagustina.wordpress.com/2012/11/26/pengertian-teori/. Diakses 9 Desember 2014

Wikipedia. (2014). Teori. (Online). http://id.wikipedia.org/wiki/Teori. Diakses 9 Desember 2014 